\title{
A Comparative Discourse Analysis of TRT World and Al Jazeera News Channels on the News Reports of the Syrian War
}

\section{TRT World ve EI Cezire Haber Kanallarının Suriye Savaşı ile İlgili Haberlerinin Karşılaştırmalı Söylem Analizi}

\author{
Şükrü SiMM ${ }^{1 \oplus}$, Fatih GÖKSU ${ }^{2 \odot}$
}

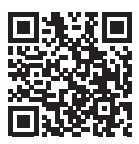

${ }^{1}$ Assoc. Prof. Dr., İstanbul University, Faculty of Communication, Cinema Department, İstanbul, Turkey

${ }^{2} \mathrm{PhD}$, Erasmus University of Rotterdam, School of Social and Behavioral Science Department, Rotterdam, Netherlands

ORCID: Ş.S. 0000-0003-3579-6750; F.G. 0000-0001-7107-3408

\section{Sorumlu yazar/Corresponding author: Şükrü Sim, \\ İstanbul Üniversitesi, İletişim Fakültesi, Sinema Anabilim Dalı, İstanbul, Türkiye E-posta/E-mail: sukrusim@gmail.com \\ Geliş tarihi/Received: 15.10.2019 Revizyon talebi/Revision Requested: 05.11.2019 \\ Son revizyon teslimi/Last revision received: 19.11.2019 \\ Kabul tarihi/Accepted: 06.12.2019}

Atıf/Citation: Sim, S., \& Goksu, F. (2019). A Comparative discourse analysis of TRT World and Al Jazeera news channels on the news reports of the Syrian war. Connectist: Istanbul University Journal of Communication Sciences, 57, 155-172.

https://doi.org/10.26650/CONNECTIST2019-0068

\begin{abstract}
In the last two decades, we have witnessed the rising of new international news networks such as Al Jazeera, Russian Today, and TRT World in order to challenge the main media corporations of the Western world like, CNN, BBC, and MSNBC, etc. particularly on the news regarding the Middle East. While the results of the Gulf War in 1990 and the invasion of Iraq in 2003 have made checks and balances on Western news associations necessary, Al Jazeera, the Qatar-based broadcaster, emerged as a remarkable voice by taking the role of a contra-flow news agency, and succeeded in producing different and original opinions within its region in the international news arena. In this context, this study selected a critical approach to TRT World, one of the recent news players in the region of the Middle East, in order to identify if it is achievable for the channel to bring a unique perspective on the news regarding the Middle East, as Al Jazeera has accomplished. A critical discourse analysis was conducted by analyzing the news reports of TRT World and Al Jazeera's stories regarding the Syrian Civil War. However, the study results suggest that TRT World misses the claim of "new and accurate perspectives 'to the international arena due to political factors.
\end{abstract}

Keywords: TRT World, Al Jazeera, discourse analysis, global media, Syrian war

öz

Son yirmi yıllık dönemde, özellikle Orta Doğu ile ilgili haberler dikkate alındığında, $C N N, B B C$ veya MSNBC gibi Batı dünyasının ana medya kurumlarına karşı, El Cezire, Russian Today ve TRT World gibi yeni uluslararası haber kanallarının doğuşuna şahit olduk. Gerek 1990 yılında yaşanan körfez savaşının sonuçları, gerekse de 2003 yılında gerçekleşen Irak'ın işgali, bir anlamda Batı́nın haber kanallarının güvenilirliği konusunda denetim ve denge faktörlerinin incelenmesi durumunu 
zorunluluk haline getirirken, özellikle Katar merkezli El Cezire kanalı, uluslararası medya arenasında, doğduğu coğrafyaya ait haberlerde yeni ve ters yönde akım oluşturarak dikkate değer bir ses olarak ortaya çıkmıştır. Çalışmamız, bu bağlamda, Orta Doğu coğrafyasında hızıı bir şekilde öne çıkan haber kanalı olan TRT World'e eleştirel bir perspektif ile yaklaşarak, kanalın El Cezire örneğinde olduğu gibi, Orta Doğu ile ilgili haberlerde özgün bir yaklaşım getirmesinin mümkün olup olmadığı konusuna eğilmektedir. TRT World ve El Cezire kanallarının Suriye savaşı ile alakalı haberleri üzerine kıyaslamalı eleştirel bir söylem analizi gerçekleştirilmiş olup, bununla birlikte, araştırma sonuçlarımız TRT World'ün politik etmenler nedeniyle, uluslararası arenaya özgün ve doğru yaklaşımlar getirme iddiasını kaçırdığını ileri sürmektedir.

Anahtar Kelimeler: TRT World, El Cezire, söylem analizi, global medya, Suriye savaşı

\section{INTRODUCTION}

News from the leading internationals networks on the Gulf War in 1990 and the events of 11 September 2001 (9/11) received considerable criticism on the basis of the news accuracy. Particularly, the invasion of Iraq in 2003 resulted in a call for better checks on the actions and collaborations of news corporations regarding the governments (Ross \& Bantimaroudis, 2006). However, particularly technological advancement created alternative new media corporations from different parts of the world that were able to attract more attention, especially regarding monitoring the news produced by the Western media. Notably, Al Jazeera, Middle East based news network, started to serve as a favourable model of a "global media contra-flow" (Wu, 2013, p. 84), as the channel broke "the Western hegemony on the news coverage" (Lynch, 2006, p. 57), gradually "became competitor to $B B C$ " or, as some scholars stated, "the channel is already more reliable than CNN as a recognized international source of information" (Bahry, 2001, pp. 91-94), bringing new perspectives and opposing those corporations in the advanced part of the world. The tendency for international broadcasting networks continued with the establishment of Al Arabiya, based in Dubai in 2003, Russian Today, based in Russia in 2005 and TRT World, based in Turkey in 2015 in order to tackle the dominancy and to benefit the media as a public diplomacy tool for strategic purposes. While a great number of studies have been conducted on Al Jazeera's capacity to compete with the Western powers, a limited number of studies focused on alternative news networks that are already active players in the Middle East or Asia that try to achieve what $\mathrm{Al}$ Jazeera managed to do: "...broadcasting global news from the unique angle from its region to the rest of the world" (Wu, 2013, p. 84). As a main element of the study, TRT World , a new international network, has also started off with a similar approach and come out in the media market as a voice of people, with a motto 'new and accurate 
perspectives'. Thus, the current study focuses on TRT World, as the latest big international news network that has not been covered in any comparative studies yet. TRT World is increasingly becoming a serious participant in the global media area. It is an international news channel with the broad range of satellite technology in Europe and Asia and it is particularly noteworthy that the network is rapidly gaining audience in the Middle East and this audience consists of Arabs living in the English spoken world. It is also based in a region that provides the channel with the potential to be a strategically serious power due to the political power relations. Interestingly, TRT World was established with a message very much alike to Al Jazeera: "Providing new perspectives" ("Our Story", 2018). Therefore, it is perceptive to investigate whether the news network powerfully gives a fresh perspective from its region to the globe, "as the world becomes more global in reach, offering perspectives on the issues that might differ from dominant Western discourses and news agendas" (Wu, 2013, p. 84). In this regard, this study begins with emphasizing discussions which followed the increasing of the brand-new media networks in the advanced world and it analyzes if these news centers achieve remarkable confrontations to the hegemony of the Western coverage or if the channels only maintain the standings of the governments of the countries that they have been based in. Besides, the paper investigates the basis of Al Jazeera's accomplishments on the contra-flow role, against the Western news networks before detailing the establishment of its counterpart, TRT World. In order to reveal whether TRT World is on the right path to come out as another Al Jazeera, the study has selected to employ a critical discourse analysis, comparing the news reports broadcasted on TRT World and Al Jazeera corporations regarding the Middle East, based on three research questions. The purpose of the study is to reveal if TRT World displayed a capacity to bring a different perspective against Western domination as Al Jazeera did and whether TRT World has been successful in providing objective and independent angle, which highlights its organizational mission.

\section{Global Media and the Progress of Al Jazeera Channel}

The late $20^{\text {th }}$ century and at the beginning of the $21^{\text {st }}$ century, we witnessed that the global media landscape added newcomers in its playground against the cultural domination of the West to the rest of the World, which resulted in the shift of the debates significantly. "Diversity and complexity of the contemporary global news media has contributed to a renewed interest in the concept of news contra-flows" (Figenschou, 2010, p. 88). Media organizations from the developing world have begun to respond 
the hegemonic news circulation from the West due to the help of "proliferation of satellite, cable television, digital technology, and the privatization of broadcasting", and more importantly the growing use of online communication and "telecommunication networks" (Thussu, 2007, pp. 11-12). Subsequently, those developments have led to "the increase in more television networks which are transnational and reach out to communities with a desire for homeland media content" (Sinclair, Jacka, \& Cunningham, 1996; Thussu, 2007, p. 33). Advances in the global media have obviously prompted the establishment of regional cultural centers based in Asia and the Middle East, which target the viewers within their own regions against the advanced West (Banerjee, 2002). However, it is not possible to claim that the era of Western domination of the global media landscape is completely dead. On the contrary, financial, technological and market conditions still favor the Western media industries. Nonetheless, as a result of these developments, scholars argued that the worldwide media arena does not completely belong to the Western hegemony as a result of the increase of new media participants and news circulation. For instance, Turkey, Russia, Qatar, and Dubai have been generating and transporting their media outputs globally. The old way of the flow of information from the West has become less influential, and scholars have begun to question the media imperialism thesis (Banerjee, 2002; Heinrich, 2008; Tracey, 1985), which reflects the substantial role of media and communication in the era of capitalism. According to many scholars (Boyd-Barrett, 1977; Tomlinson, 1991; Friedman, 1994; Schiller, 1992), media imperialism was introduced in the 1960s, which involves a process where a stronger nation dominates the weaker ones in the terms of media and it is a form of indirect imperialism, where the minds of the people have been influenced through the foreign media that adapts some methods, such as owning a media network, deciding the content of the news, programs, and influencing the production-distribution processes. However, the rise of the new players in the global media has interrupted this drift, by "creating a new media landscape", which is able to bring different angles and perspectives to the public sphere (Volkmer, 2003, p. 11). One and maybe the most important new player in the global media world is Al Jazeera. The channel was established in 1996 in Qatar, and according to Lynch (2006, p. 61), "has been the most prominent product of the satellite revolution". Initially, the channel was to compete with the $B B C$ or the CNN in the media landscape and to bring a "new and modernized picture of Qatar into the rest of the world" (Seib, 2005, p. 601). The network that benefits from new technologies is relatively independent and is not considered as a platform for political or governmental elites, although the owner of the network is from the country where it was born. This semi-independent channel has provided critical information 
about the governments, started constructive-social differences in the area and eventually caused serious damages to the despotic Arabic regimes (Wojcieszak, 2007; Lynch, 2005). Therefore, many scholars claim that $A l$ Jazeera has become a dominant power rather than a media channel in the Arab world. Zayani (2005) argues that the reasons why $A$ l Jazeera has become successful are that it came from a region that exercised despotic regimes control in media and there have been a large number of angry audiences that were "hungry for a station that could stand up to authoritarian Arab governments" (Wu, 2013, p. 85). Al Jazeera was also born in a "region where the conflicts and wars" have been taking places all over the decades, such as Iraq, Afghanistan, Palestine or Syria (Zayani, 2005, p. 6). In addition, the invasions of Iraq and Afghanistan by the US after the $9 / 11$, were directed to the regions where $A$ I Jazeera formed out as a unique new source of information (Lynch, 2006). All these reasons have provided the channel with an opportunity that straightforwardly counters the Western news network and have made the news channel a player that is able to present an opposite side of the story. According to Nigel Parsons, Former Managing Director of the channel, the network is 'credible, balanced and alternative to the Western media' (Tatham, 2005). Indeed, for the first time in history, the Western media finds itself without a monopoly on the coverage of important events, such as the news regarding conflicts (Zayani, 2005, p. 29). Researchers, therefore, have characterized the channel as the first reasonable, superbly financed media network with a distinct angle to the international news (Nawawy \& Iskandar, 2003; Powers, 2009; Painter, 2008). According to the official Al Jazeera English website, the network is "balancing the current typical information flow by reporting from the developing world back to the West and from southern to northern hemisphere. The channel gives voice to untold stories, promotes debate and challenges established perceptions" ("A Truly Global...", 2018). At the same time, the network emerges, as its persistence on revealing fragile political, social, economic even religious issues, including conflicts or corruption between Arab nations. Officials in Al Jazeera have frequently stated that the channel actually created a rift between Qatar and several Arab nations due to the station's criticism of various regimes, including Jordan, Kuwait and Palestinian and many images were shown in the channel that actually damaged the image of the Muslim world in the name of objectivity, such as the Taliban destroying the Buddha statues in Afghanistan (Samuel-Azran, 2010, Zayani, 2005, p. 3). It is true that the channel is the only kind in the Arab world that covers issues related to corruption and polygamy. But there has also been also a great deal of criticism on Al Jazeera, especially regarding the content and the issue of funding since its launch. The channel was promised to get privatized in the first five years after the establishment, yet the 
station is still largely funded by the Qatari Emir, which caused criticism on the question of the independence and the objectivity of the station (Tatham, 2005). Besides, the achievements of the channel, particularly, against Western hegemony brought some challenging debates. Thussu $(2007$, p. 2 ) claims that "it is generally through organizations that the Western media maintains its ideological structures through the localization of the Western content to fit local cultures". Also, the improvement and the variety in media landscape do not mean better conditions for people to choose and to express ideas. According to Galtung (1971), the interests of the controlling groups that are delivered because other groups would have learnt, in fact, forced to play generalized roles as dominant and dependent. Thussu goes back and explains the issue from the media imperialism aspect: “Circulation of the cultural mixtures and the global dominant flows might be becoming more powerful as these negotiated cultural products which are legitimized by unsuspecting audiences as being a more acceptable outcome of the globalization even as they reproduce the Western ideologies and the genres" (Thussu, 2007, p. 19). One should know that the content of the news channels sometimes rely on the global media companies, which are located in the Western part of the world, for their products of the media content related to developing countries in the Middle East or Asia. These relatively new channels adopt the same structures of newsworthiness, such as "credibility, visual appeal and ability to be packaged" (Wu, 2013, p. 87). The reporting of the foreign news is considerably based on these agencies to a large extent, including TRT World, whose external news content is delivered by the Western companies to a large extent, such as Associated Press or Reuters. Having said that, it is interesting to investigate what TRT World can propose to worldwide public viewers and if the channel has the capacity to become a media company that is capable of producing different and new angles in the Middle East.

\section{TRT World News Channel as Another Al Jazeera}

TRT World is a brand new news network based in Istanbul, Turkey with offices in London U.K., Washington, the USA and the network is becoming a more important actor in the universal media field. It is an international news channel with a broad range of satellite technology in Europe and Asia and it is specifically notable that the network is attaining audience rapidly in the Middle East and this audience consists of Arabs living in the English speaking world. TRT World is a public service channel currently under the organization of the Turkish Radio Television (TRT), which is the largest broadcaster and the biggest media organization in Turkey. Although TRT is a public 
enterprise and the Turkish government assigns the directors of the board, in accordance with Article no 133 of the Constitution, TRT adopts impartiality as an objective public entity. Established in May 2015, TRT World has gradually become an important network, especially in the Middle East. The channel supplies English language news from the main three offices to the rest of the world. Since the beginning of the channel, TRT World has been "available in more than 190 countries and carried by major TV platforms and streaming devices across the world" ("Our Story", 2018). However, TRT World is still considered a predominantly regional enterprise and it is not considered to be global yet when compared to the other actors, such as CNN, Al Jazeera, BBC, and Bloomberg, etc. As a result of the political developments in the Middle East and the rise of the new economic powers in the region, TRT World has found itself in a privileged position. The sort-term of political stability and the advancements in the international relations have definitely helped TRT World to be born ("Our Story", 2018). The channel was established with the mission to offer "different perspectives" laying out its vision to "become an international voice of authority from Turkey" and to offer its news from an objective angle to the rest of the world ("Turkish TV Station...", 2016). Interestingly enough, Ibrahim Eren, the CEO of the station, has addressed the shift of their editorial policies. While Eren has mentioned that they are balanced news channel and they do not have a pro-Turkey stance, he has accepted that their tone of news changed after the $15^{\text {th }}$ of July 2015, due to the coup attempt in Turkey (Ünal, 2016). In this regard, to reveal whether TRT World accomplishes its vision of 'providing different perspectives' ("Our Story", 2018) we selected to analyze the two conflict stories regarding the Syrian War, covered by the station since its launch, against the broadcast of the same news of $A l$ Jazeera channel. The main aim of the study is to find out if TRT World's coverage brings a different and objective perspective as the way Al Jazeera covered the events. Besides, the study wishes to reveal if the channel functions within the global media contra-flow that can challenge the Western discourses. Here, this study refers to the key elements of $A$ l Jazeera's news stories and adapts them as a basis for our research questions.

\section{AIM AND METHODOLOGY}

According to Schwalbe, when a"form of discourse is established as standard practice, it becomes a tool for reproducing inequality, because it can serve not only to regulate the thoughts and emotions but also to identify constructed others" (Schwalbe, Godwin, Holden, Schrock, Thompson, \& Wolkomir, 2000, pp. 433-434). In the case of the media, the commentaries on production, reception, and interpretation of the messages are 
inclusive and underlying. Thus, discursive analysis is especially beneficial, as it allows textual analysis to be apprehensive of the global as well as local social context within which the text is generated and received. In this manner, as a methodological tool, the study employs comparative discourse analysis to investigate the discursive practices. More specifically, in order to investigate the extent to which TRT World highlights the elements of a media contra-flow like Al Jazeera, the paper preferred to conduct a comparative discourse analysis on two conflict stories of TRT World and Al Jazeera networks in the Middle East region, regarding the Syrian War. Two main stories have been chosen for analysis based on the news items that were displayed most prominently on two channels, that is, as top stories in the bulletins and with the highest frequency.

a1) The Turkish-backed Free Syrian Army forces took full control of Al-Bab city, as a part of the Operation Euphrates Shield. (Main story for TRT World during and after the operation, 70-90 days - Main story for Al Jazeera during and after the operation for 30-45 days).

b1) Syrian Democratic Forces (SDF) seized the full control of Raqqa city against Islamic State (ISIL). (Main story for both channels after the city captured for 15-25 days).

These stories have been particularly chosen for various reasons. Firstly, both stories make a good example to see if TRT World keeps its promise to be objective as the stories were related to Turkish foreign policy's ambition. Secondly, the Turkish government recognizes SDF as a terrorist organization; therefore, SDF's progress in Syria puts TRT World in a peculiar position of having to deal with the complexity in narrative structure.

For the analysis, the paper adopted a critical discourse analytical framework by Normal Fairclough. The news packages were watched several times to identify the discourses based on two acts in the study. Notes were taken regarding the 'news content', 'the number of sources,' 'locations,' interviews', 'thematic tendencies', 'focus of the news,' differences or similarities on the coverage'. Notes and findings were categorized and analyzed in the light of Norman Fairclough's (1992) critical discourse structure to investigate the news discourses through components such as langue used, framing of the story and the ideologies and assumptions embedded in the text. Here the paper used three research questions to guide the analysis, using the elements of Al Jazeera's news stories as reference: 
RQ1: Does TRT World provide alternative perspectives within the news reports as $A$ I Jazeera does?

RQ2: Does TRT World have an independent editorial voice on the issue raised?

RQ3: Does TRT World have sufficient correspondents reporting in the locations to provide different perspectives?

For this study, the paper emphasized three aspects for the analysis: (1) How the story was framed and voices were used, (2) how the issue was raised, and (3) the locations of journalists by adapting the analyzing method of Roy's and Ross' study (2011) on the media commentary regarding terror events in three countries, -the US, India and Scotland-in order to explore and compare the media's role in the construction of ideological conceptions, as their findings suggested that the media partook of and contributed to global ideological discourses. Our paper particularly studied whether TRT World and Al Jazeera used 'different frames', 'angles' or 'viewpoints' for the news events and also explored the situation in the news stories according to how the news was defined; if the pictures and voices basically supported the dominant perspectives or certain groups. It was also pivotal to check if the opposing viewpoints were present in the news stories and if the stories were critical ones and the paper analyzed the level of criticism. Additionally, the paper paid attention to the discourses of journalists to see if they were highlighting the particular perspective on the issues over others.

\section{FINDINGS}

The samples of the news packages were obtained from TRT World and Al Jazeera's official YouTube accounts. The time frame of the sample selection is 1 year, 3 months and 3 days between $24^{\text {th }}$ of August 2016 and $27^{\text {th }}$ of October 2017. The total of 78 news packages, 27 from the Al Jazeera and 51 from TRT World, were examined. TRT World broadcasted more news items than Al Jazeera during the same period. Therefore, it possible to state that TRT World spared much more time duration of news packages (TRT World $205 \mathrm{~min}$ and Al Jazeera $93 \mathrm{~min}$ ). The reason is that TRT World news packages are generally longer and each clip covers the abovementioned conflicts through more in-depth and frequent news formats, while the Al Jazeera covers the conflict in shorter formats. 


\section{The Use of Story Frames and Voices}

Regarding RQ1 addressing the use of the frames and the voices, our data reveals that both TRT World and Al Jazeera are prone to adapt their coverage on the events or on the developments traced by the government's news conferences or announcements. For example, both stations would start their stories (a1) about the Turkish backed military operation in Al-Bab in Syria with updates from the Turkish governments' officials on the progress of the battle against ISIL (The Islamic State of Iraq and the Levant). However, the news (b1) about the SDF's (Syrian Democratic Forces) control on Raqqa significantly differs. Al Jazeera again initiated its story (b1) with a headline 'SDF forces took full control of Raqqa', and with a sound bite from the SDF's officials explaining that ISIL has been removed from Raqqa. The network also used the images from the SDF forces and their celebration in the location. In the meantime, TRT World adopted (b1) particularly the US involvement in the coverage with a headline 'US-backed SDF fully control of Raqqa', with no images of the SDF forces in the package. At the same time, regarding news (b1) about that Raqqa was captured by SDF forces, Al Jazeera included the official spokesman's voice and the images of the Kurdish-led Syrian Democratic Forces for the coverage and based the news on the official sources, taken by AFP news agency. Different from Al Jazeera, TRT World's approach to the same story (b1) only included the official voices and images of the high-ranking US military officials, and detailed the frames, displaying the effects of the war in the city since the beginning of 2011. The news angles delivered by TRT World on the involvement of the SDF forces in Raqqa (b1) are an example of how TRT World's presentation of news is influenced by the political spectrum in Turkey. In the news package presented on the October $20^{\text {th }}$ 2017, TRT World refers to SDF (Syrian Democratic Forces) as YPG (People's Protection Units), militants who are the military branch of Kurdish Democratic Union Party and refers to YPG as a terrorist organization. YPG is regarded as a terrorist group that has been formed in northern Syria by Turkey and they are the branches of PKK ${ }^{1}$ (The Kurdistan Workers Party), which has been violently active in the south of Turkey since 1989. The same news package (b1) also presented the frames of the SDF's forces waving a flag that has the pictures of Abdullah Ocalan, who is the head of PKK organization jailed in Turkey. The headline of the news (b1) was presented in TRT World, as 'SDF raises a banner in Raqqa showing PKK leader'. The package injected a sound bite of the Turkish President Recep Tayyip Erdogan asking that'...you see terrorist PKK leader flag in Raqqa. How does the US explain it to Turkey now?' The same news package (b1) continued with the reporter's voice arguing that the flag in Raqqa, which is a Syrian city, is a public 
embarrassment for the US. Unlike TRT World's straightforward coverage of Raqqa, which has the elements of foreign policy approaches of the Turkish Government to the Kurdish groups in Syria, Al Jazeera presented (b1) a rarely-seen side of the conflict and gave a voice to the local people, and also provided insights into elements beyond the actual conflict. Additionally, Al Jazeera appeared more unbiased and more objective than TRT World in presenting its news (a1-b1) with straight reports of uncontentious events or issues, since it was laid out by the official sources, such as different governments or well-known international organizations. For instance, Al Jazeera's story (a1) about the control of the Turkish backed FSA forces in Al-Bab on $16^{\text {th }}$ February 2017 was reported entirely from the viewpoint of the official sources, which firstly started with a speech by the Turkish President, and later continued with Russian and American officials for their different opinions. TRT World raised a voice in the introduction piece focusing on the capabilities of the Turkish backed FSA group to fight against the ISIL in Syria, instead of using the US-backed SDF forces at the same time when there was no role of the Kurdish forces related to Al-Bab city, a news package (a1) on the $10^{\text {th }}$ February 2017. An editorial voice mentioned that'... letting SDF forces to Raqqa will be a national security matter to Turkey', before playing a reporter's prepackaged story on the control of Al-Bab. The news report also included a sound bite from the Former Turkish Deputy Prime Minister's explanations on the threats that result from Kurdish groups' ambitions to gain more territory in Syria. This was the only official voice and source used in the news package. The story (a1) took a different turn thereafter, with a focus on other operations that Turkey might intend to start with reporter's similar comments to Turkish Governmental sources.

\section{Editorial Voice on the Issue Raised}

Regarding the RQ2 addressing editorial voices on issues raised regarding TRT World suffers from the broadness and profundity compared to Al Jazeera. Fewer or specifically chosen issues were brought into for discussion, and the station guiding clearness on issues were not been established within the official parameters. TRT World began its story (a1) about Al-Bab on $13^{\text {th }}$ March 2017 after the seize of the city by stating that how people in Al-Bab were waiting to be saved from ISIL.'Residents recount horror under DAESH ${ }^{2}$ rule.' The news package included the sound bite from a civilian talking to camera about the help of the Turkish-backed FSA forces. The news report also included the reporter's voice explaining that the people in Al-Bab trust Turkish army and Turkish backed FSA forces on the cleaning the mines and on the 
reconstruction of the city. However, the reporter claimed that people did not want to speak on to the camera, as they were still scared. Evidently, TRT World raised points that impartially fell within the favors of the capturing Al-Bab city. Al Jazeera coverage (a1) on Al-Bab, after the Turkish-backed forces captured the city, sought to question the intentions of Turkey from a broader perspective. The news package focused on Turkey's plan to move forward to Raqqa in Syria in order to save the city from ISIL, together with the US forces. Story voiced '... Turkey set sight on ISIL capital Raqqa' with a sound bite of Turkish President Recep Tayyip Erdogan'....After this, the next targets in the East are Manbij and Raqqa, we shared our thoughts with the new US administration and we will wait for the developments'. However, reporter raised the issue on the package saying that 'such a move to ISIL stronghold of Raqqa, $180 \mathrm{~km}$ from Al-Bab, was not the goal when the operation to Al-Bab started nearly six months ago. Aside from ISIL, Turkey wants to push back its enemies, the Kurds, from this area'. The package also raised the issue regarding the situation of the civilians, emphasizing that the battles always damage and harm civilians most. Therefore, news clip demonstrated Al Jazeera's tendency for critically examining the issues and concerns that might be linked to news events, rather than generating the story with a language approved by the authorities. The analysis of the post-packages (b1) on the SDF' forces control of Raqqa city indicate that TRT World's stories on the $19^{\text {th }}$ October, 2017 and on the $4^{\text {th }}$ December, 2017 were relatively long and basically straight reports that explain the military structures of the SDF forces and the damage given by them to the cities and the civilians. On $19^{\text {th }}$ October 2017, the package started to show the images of Raqqa after the ISIL-SDF fight and stated that they have destroyed the city in the battle to capture it and the civilians cannot go back to the heavily damaged houses. News clip also provided the sound bites of the refugees who have been living in Turkey and the refuges have told the reporter that the SDF forces, regime forces and ISIL have no difference in harming the civilians. Particularly, on $4^{\text {th }}$ December 2017, news package (b1) aired an interview with a former SDF spokesperson, confessing that YPG, the SDF's military branch, has been formed by the PKK terrorists who are active in the South of Turkey. Interviewee also claims that YPG has had a secret deal with ISIL fighters in Raqqa in order to evacuate them safely. None of the packages included formal voices or analysis but the issue was raised according to the perspective of Turkey's foreign policy on the Syrian War. However, Al Jazeera, after a post-packaged story (b1) regarding the capture of Raqqa by the SDF forces, continued its coverage by providing audiences in-depth background information on the tensions between Turkey-US and SDF forces. After providing the overview, Al Jazeera presented the news reports to audiences with 
a critical debate on the responsibility of the US-backed SDF forces towards the civilians in Raqqa. News continued to include two completely opposing viewpoints about who was to blame for the increasing number of civilian casualties in the fight against the ISIL. One of the interviewees, Syria Consulting Research Fellow from Chatham House Haid Haid, repeatedly made the point that '... reports and locals have confirmed that during and after of Raqqa battle with ISIL, civilians have been killed by the US led coalition and we do not know the exact scale of the number. Now that the war is over, at least in Raqqa, we should be able to get into the city and verify the facts and numbers'. This interview was followed by another that raised the opposing viewpoint to the same issue. Another interviewee was Joshua Landis, Professor at the Center of Middle East Studies, The University of Oklahoma and argued that'... if we look at the Syrian-Russian coalition, we see the same thing, the bombing of Aleppo, Homs or other suburban areas of Syria. All of these places are under the same situation and we see how difficult urban warfare is and every army uses this big scale of bombings in order to win the battle, which means breaking the moral code'. While the claims of Professor Landis were not highly strong and well articulated, the coverage of Al Jazeera was creditable for its attempt to put forward more issues for debate and to question the perspectives of the official government sources. This meant that audiences might become more politically aware and better informed to have their own perspectives and conclusions.

\section{Locations of Journalists}

Regarding the RQ3, despite praising itself on its extensive network of the correspondents in the Middle East region, who are able to report events on locations and provide unique insights, TRT World fell short in its coverage (b1) of the capture of Raqqa by the SDF forces. However, as a result of both the advantages of locations, and the involvement of the Turkish army in the battle of Al-Bab, TRT World has sufficiently proved some success on the coverage of the news (a1). On the coverage of Raqqa (b1), TRT World has never reported from the location and mostly conducted short phone interviews or had guests on the studio with its correspondents in Gaziantep, which is one of the biggest and the closest city to the conflict site in the south of Turkey. In the meantime, Al Jazeera has had correspondents on the location and reported inside of Raqqa and from Gaziantep city, like TRT World. In terms of the stations' coverage on the capture of Raqqa by the SDF forces, on 17 October 2017, for instance, while both TRT World and Al Jazeera both used the same story frames with the latest images of Raqqa, Al Jazeera focused on the advancement of the SDF. Moreover, the official voices of both 
SDF and US were injected; the reactions from Syrian-Russia coalitions and European countries were voiced, such as reporters on the camera from England. On the other hand, TRT World was purely interested in the contribution of US forces and SDF's relation with PKK organization without any reporter on the news package. For other news stories regarding the capture of Raqqa by the SDF (b1), TRT World took the angle of the Turkish official source, displaying the Turkish President's warning about the support of the US for the Kurdish forces on the conflict area during their expansion. After the overview of the SDF's gains and the support of the US in the story, the anchor went on speaking with TRT World's Syrian War reporter based in Gaziantep to hear his comments of the news involving US-Kurdish relations. Al Jazeera coverage (b1), on the other hand, featured a pre-packaged story from its correspondent in location, which led off with images of SDF forces and the civilians and the ruins of Raqqa and offered an insight into the people's point of view before cutting to sound bites from the SDF and the US officials meetings. Here, Al Jazeera correspondent, present in location, took the opportunity to soak into the story with the view of the people in Raqqa and collected new images from the ground, rather than conveying information about the official event. Having said that, TRT World has achieved the same success on the news stories (a1) regarding the capture of AI-Bab by ISIL after making use of the advantages presented before. Just after the end of the battle, TRT World had reporters and presenters on the ground both in Al-Bab and in Kilis, a Turkish city that is closest to Al-Bab. News packages prepared by reporters in front of the camera demonstrated new images after the battle as well as the sound bites from local people. Even if TRT World's angle was reflecting the Turkish Government approach, people raised different voices in the stories. But the packages did not have reporters delivering the reactions from the other sides of the Syrian War, but rather its correspondents were talking from the main studio about the next steps. Al Jazeera, on the other hand, seemingly left the ground to TRT World in Al-Bab (a1). In 2012, when the rebels' forces took the control of Al-Bab from Syrian government forces, Al Jazeera, being the only one in the city, reported closely about the rebel forces advancing into and capturing Al-Bab with war reporters next to rebel fighters. On the contrary, when it came to Turkish backed FSA capturing the city in 2017 (a1), Al Jazeera only reported from Gaziantep, Turkish city, from the beginning to the end. Even when Al Jazeera did not have reporters in Al-Bab, they aired their news packages with a wide range of aspects and reactions from different locations.

It will be fair to claim that TRT World presented relatively straight reports on both news stories. However, Al Jazeera made better use of its reporters, by applying its on- 
location correspondents to produce more holistic news that went beyond official sound bites to include images and voice of every side, and to provide more in-depth analysis on both news stories.

In brief, the coverage of the Syrian War proves that TRT World breaks its promise to deliver the different and objective perspectives on global developments, whereas $A I$ Jazeera, the contra-flow news network, offers successful insights even for the stories that originated from its own region. Despite having reporters in all the major cities around the globe, TRT World's reports (b1) regarding the Raqqa's and Al Bab's seizure (a1) involved few correspondents and fewer objective voices than Al Jazeera's coverage. TRT World's reporters were not fully adapted to the methods to provide insights into issues of critical concern, such as the tensions between the Syrian coalition and the US coalition and the role of SDF forces in Syria. However, the station raised the issue of the possibility that the SDF forces have damaging effects on civilians in Raqqa. Nonetheless, the network fell short again regarding the US involvement in the civilian deaths during the war against ISIL, particularly in Raqqa. Moreover, Al Jazeera gathered new images and opinions from people on the ground, especially before and after the seizures of the cities (b1), whereas TRT World relied on Turkish officials' sources and delivered the news with sound bites of the Turkish authorities with reporters repeating the same messages. These findings strongly suggest that TRT World is adopting more statist discourse in its news coverage, while Al Jazeera moves beyond the official line to include more different and objective voices. This can be explained by the fundamental differences in the news models adopted by TRT World and Al Jazeera. Al Jazeera relatively operates with an independent model like 'Libertarian Model' introduced by Siebert and his colleagues, where the channel seems objective and reports for the search of the truth by presenting different perspectives and arguments to audiences, so that they can find their own conclusions and be free from any authority or any control or censorship. On the other hand, TRT World's news functions in a model that Siebert's "Authoritarian Model". According to this model, "media is used as a mouthpiece for the leadership to convey information and policies to people" (Siebert et. al, 1956, p.1-2.). Here, the media operates with the top authorities and the governments have full control and censor.

\section{DISCUSSION AND CONCLUSION}

Evidently, Al Jazeera is a notable example of the concept of global journalism as defined by Berglez, which is "a network that is endowed with the global outlook" 
(Berglez, 2008). As argued by Wojcieszak, Al Jazeera "operates within a geopolitical reality where the restrictions and influences are transnational, and thus escapes the notion of state influences on national media" (Wojcieszak, 2007, pp. 118-120). Since $A /$ Jazeera is independent from domestic regulations and power relations, there is no reason for the network to have a perspective of the national power structure and to obey the views of its political elites. On the other hand, this study reveals that TRT World employs official discourses, legitimized patriotic views, imposed political strategies and nationalistic messages, instead of challenging officials that are frequently quoted in its news stories and endorsed by the reporters. The Turkish government has a direct impact on the content and the type of news stories broadcast in TRT World. As it can easily be tracked by the news packages prepared and presented regarding the Syrian War, the danger of being under the public broadcaster's umbrella is clearly apparent. A report on the 'Media Pluralism' ("Monitoring Media Pluralism...", 2017) has already revealed that TRT network functions as a state-media, far away from being a public service media and operates as a government propaganda tool, especially, during local elections. When reporters receive the news contents from the government officials, not only to report on conflicts but also to have information about the security of the country or human rights or about the domestic and international issues, the politics serves as the main sources of information that eventually direct journalist to have a dependent perspective. As the coverage of TRT World mostly relies on official sources for its reports rather than on different and objective voices, the study argues that the network functions to assist the Turkish government to achieve better results on the foreign policy, which means that the editorial policies of TRT World are unlikely to be objective and might have problems regarding accuracy. Finally, while the political issues are regarded as sensitive in terms of the Turkish government, the objectiveness of the media will be out of the table in the name of national interests. All these factors plainly suggest that TRT World has a tendency towards a statistic discourse in its news reporting, and the network offers clear evidence of partiality.

\section{ENDNOTES}

1. Countries such as Turkey, US, Canada, New Zealand or organizations such as European Union and NATO accept PKK as a terrorist group ("Country Reports...", 2018).

2. Turkish Government and TRT World refers to ISIL as DAESH. 


\section{REFERENCES}

A Truly Global Network. (n. d.). Retrieved December 22, 2018 from https://www.aljazeera.com/aboutus/

Azran, T. S. (2013). Al Jazeera, Qatar, and new tactics in state-sponsored media diplomacy. Journal of American Behavioral Scientist, 57(9), 1293-1311. https://doi.org/10.1177/0002764213487736

Bahry, L. Y. (2001). The new Arab media phenomenon: Qatar's Al Jazeera. Middle East Policy, 8(2), 88-99. https:// doi.org/10.1111/1475-4967.00020

Banerjee, I. (2002). The locals strike back? Media globalization and localization in the new Asian television landscape. Gazette: The International Journal for Communication Studies, 64(6), 517-535. https://doi.org/10.1177/174804 85020640060101

Berglez, P. (2008), What is global journalism? Journalism Studies, 9(6), 845-858. https://doi. org/10.1080/14616700802337727

Boyd-Barrett, J. O. (1977). Media imperialism: Towards an international framework for the analysis of media system. In J. Curran, M. Gurevitch, \& J. Woollacott (Eds.), Mass Communication and Society, (pp. 116-135). London, UK: Open University Press.

Country Reports on Terrorism 2017 - Foreign Terrorist Organizations: Kurdistan Workers' Party. (2018, 19 September). Retrieved from https://www.refworld.org/docid/5bcf1f364.html

El-Nawawy, M., \& Iskandar, A. (2003). Al-Jazeera: The story of the network that is rattling governments and redefining modern journalism. Colorado, USA: Westview Press.

Fairclough, N. (1992). Discourse and text: Linguistic and intertextual analysis within discourse analysis. Discourse \& Society, 3(2), 193-217. https://doi.org/10.1177/0957926592003002004

Figenschou, T. U. (2010). A voice for the voiceless?: A quantitative content analysis of Al-Jazeera English's flagship news. Global Media and Communication, 6(1), 85-107.

Friedman, J. (1994). Cultural Identity and Global Process. London, UK: Sage Publications.

Galtung, J. (1971). A structural theory of imperialism. Journal of Peace Research, 8(2) 81-117. Retrieved from www. jstor.org/stable/422946

Heinrich, C. D. (2008). The death of cultural imperialism and power too? A critical analysis of American prestige press representations of the hegemony of English. International Communication Gazette, 70(5), 378-394. https://doi.org/10.1177/1748048508094289

Lynch, M. (2005). Watching Al Jazeera. Wilson Quarterly, 29(3), 36-45. Retrieved from www.jstor.org/stable/40233061 Lynch, M. (2006). Voices of the new Arab public: Iraq, Al Jazeera, and Middle East politics today. New York, USA: Columbia University Press.

Monitoring Media Pluralism in Europe: Application of the Media Pluralism Monitor 2016 in the European Union, Montenegro and Turkey. (2017). European University Institute, Centre for Media Pluralism and Media Freedom. Retrieved from https://cadmus.eui.eu/bitstream/handle/1814/46786/CMPF-MPM_PolicyReport2017.pdf Our Story. (n. d.). Retrieved December 24, 2018 from https://www.trtworld.com/about 
Painter, J. (2008). Counter-hegemonic news: A case study of Al-Jazeera English and Telesur. Oxford, UK: Reuters Institute for the Study of Journalism.

Powers, S. (2009). The geopolitics of the news: The case of the Al Jazeera network (Doctoral dissertation, University of Southern California, California). Retrieved from https://www.academia.edu/556090/The_Geopolitics_of_ the_News_The_Case_of_the_Al_Jazeera_Network

Ross, S. D., \& Bantimaroudis, P. (2006). Frame shifts and catastrophic events: The attacks of September 11, 2001, and New York Time's Portrayals of Arafat and Sharon. Mass Communication and Society, 9(1), 85-101. https:// doi.org/10.1207/s15327825mcs0901_5

Roy, S., \& Ross, S. D. (2011). The circle of terror: strategic localizations of global media terror meta-discourses in the US, India and Scotland. Media, War \& Conflict, 4(3), 287-301. https://doi.org/10.1177/1750635211420631

Schiller, H. I. (1992). Mass communications and American empire. Colorado, USA: Westview Press.

Seib, P. (2005). Hegemonic no more: Western media, the rise of Al-Jazeera, and the influence of diverse voices. International Studies Review, 7(4), 601-615. Retrieved from www.jstor.org/stable/3699677

Siebert, F. S., Peterson, T., \& Schramm, W. (1956). Four theories of the press. Illinois, USA: University of Illinois Press. Sinclair, J., Jacka, E., \& Cunningham, S. (1996). Peripheral vision. In J. Sinclair, E. Jacka, \& S. Cunningham (Eds.), New patterns in global television: Peripheral vision (pp. 1-32). Oxford, UK: Oxford University Press.

Schwalbe, M., Godwin, S., Holden, D., Schrock, D., Thompson, S., \& Wolkomir, M. (2000). Generic processes in the reproduction of inequality: An interactionist analysis. Social Forces, 79(2), 419-452. https://doi.org/10.2307/2675505

Tatham, S. (2005). Al-Jazeera: can it make it here? British Journalism Review, 16(1), 47-52. https://doi. org/10.1177/0956474805053360

Thussu, D. K. (2007). Media on the move: Global flow and contra-flow. London, UK: Routledge.

Tomlinson, J. (1991). Cultural imperialism: A critical introduction. New York, USA: Continuum.

Tracey, M. (1985). The poisoned chalice? International television and the idea of dominance. Daedalus, 114(4), 17-56. Retrieved from www.jstor.org/stable/20025009

Turkish TV station aims to switch western views. (2016, March 11). Financial Times. Retrieved from https://www. ft.com/content/cd5d7f46-e77c-11e5-a09b-1f8b0d268c39

Ünal, A. (2016, November 21). TRT World Ceo İbrahim Eren: We will tell the truth, even if it is inconvenient or disturbing. Daily Sabah. Retrieved from https://www.dailysabah.com/turkey/2016/11/21/trt-world-ceoibrahim-eren-we-will-tell-the-truth-even-if-it-is-inconvenient-or-disturbing

Volkmer, I. (2003). Global network society and global public sphere. development, 46(1), 9-16. https://doi. org/10.1177/1011637003046001566

Wojcieszak, M. (2007). Al Jazeera: A challenge to traditional framing research. The International Communication Gazette, 69(2), 115-128. https://doi.org/10.1177/1748048507074925

Yayın İlkelerimiz. (n. d.). Retrieved January 9, 2019 from https://www.trt.net.tr/Kurumsal/Yayinllkelerimiz.aspx

Zayani, M. (2005). The Al Jazeera phenomenon: Critical perspectives on new Arab media. London, UK: Pluto Press. 